\title{
The Small World in Which the Great World Holds its Rehearsal
}

\author{
Das Gedächtnis Zentraleuropas: Kulturelle und literarische \\ Projektionen auf eine Region. By Moritz Csáky. \\ Vienna-Cologne-Weimar: Böhlau Verlag, 2019. 392 pp.
}

Imre Tarafás

Department of Modern and Contemporary World History, Faculty of Humanities, Eötvös Loránd University, H-1088 Budapest, Múzeum krt. 6-8., Hungary;

tarafas.imre@btk.elte.hu

\begin{abstract}
"Misunderstanding of the present is the inevitable consequence of ignorance of the past. But a man may wear himself out just as fruitlessly in seeking to understand the past, if he is totally ignorant of the present. [...] [T] he scholar who has no inclination to observe the men, the things, or the events around him will perhaps deserve the title [...] of a useful antiquarian. He would be wise to renounce all claims to that of a historian."
\end{abstract}

Although Moritz Csáky is less stern than the above-quoted Marc Bloch, because he considers a "general interest in history" equally legitimate grounds for historical research as the intention of orienting ourselves in the present; his latest book demonstrates that for him as well, the study of the past is the path to understanding the problems of our present. The aim of Das Gedächtnis Zentraleuropas: Kulturelle und literarische Pojektionen auf eine Region is to give a conceptual framework and comparative material to understand the phenomena of globalization. For this, Csáky chooses the study of Central Europe: a region which is defined by difference, plurality, and heterogeneity, a region where conflictual cultural processes once took place that are comparable to the present issues of the globalizing world. This Central Europe escapes virtually all traditional definitions, nevertheless, it gained a concrete political-geographical form in the image of the Habsburg Empire, which consequently provides the focus for Csáky's book. As a result, historical Austria becomes

1 Bloch, The Historian's Craft, 36-37. 
once again, to quote the famous poem by Friedrich Hebbel, the "small world" in which the "the great world holds its rehearsal." 2 While some four decades ago, it was the problem of modernity that preoccupied researchers of fin de siècle Vienna, in Csáky's vision, it is globalization that the great world rehearsed in the small one, in the Empire of the Habsburgs. Nevertheless, the book provides important perspectives on Viennese modernity as well. It shows that the remarkable achievements of fin de siècle Vienna can be attributed to the stimulating nature of a heterogenic cultural context, rather than a hedonistic turn from politics to aesthetics, as Carl E. Schorske argues in his landmark Fin de siècle Vienna: Politics and Culture. ${ }^{3}$

Csáky's latest book can be considered a synthesis of the historian's main ideas, expounded in a great number of monographs and studies. Hence, it is the outcome of decades of dedicated research. It was around the mid-eighties that Csáky's interest turned to the field of cultural history. His first major work in this direction was the 1996 Ideologie der Operette und Wiener Moderne: Ein kulturhistorischer Essay zur österreichischen Identität. ${ }^{4}$ In my view, this has been Csáky's greatest achievement. Its original structure is exemplary in its ability to transmit the main message about how the genre of the operetta perfectly reflects the cultural plurality of the Central European region. Its historiographical significance lies in its ability to combine the Anglo-Saxon and the Austrian approach to "Vienna 1900." Austrian historians had been critical of scholars preoccupied with Viennese modernity for using a narrow concept of culture, concentrating solely on "high culture" while completely neglecting the experience of everyday life, the perspective of the "small man" viewing the world. ${ }^{5}$ It was against this academic background that Csáky managed to examine the two levels simultaneously, pointing out the occasions when the two intersected. Additionally, it is striking that while Anglo-Saxon scholars tend to see the Monarchy as an anachronism sentenced to death by its multinational makeup, Csáky, who spent his childhood in a multilingual environment (German, Hungarian, and Slovak), is not startled by this situation; on the contrary, he regards as viable the coexistence of different nationalities in the culturally plural Habsburg Empire. Finally, one cannot but marvel at the scholar's profound knowledge and genuine love of culture that compares only to the quality of Carl E. Schorske's work.

According to an interview Csáky gave to the Hungarian Aetas review, Das Gedächtnis Zentraleuropas had been a long-term project. ${ }^{6}$ Furthermore, it can

\footnotetext{
2 Hebbel, "Prolog zum 26. Februar 1862."

3 Schorske, Fin de siècle Vienna.

$4 \quad$ Csáky, Ideologie der Operette.

5 Cp. Szívós, "A másik Bécs."

6 "I am preoccupied with the idea of writing a synthesis of the cultural history of the Central European region.” Deák, “Európa kicsiben,” 240.
} 
be considered a continuation of the operetta book, in the same way as the 2010 Das Gedächtnis der Städte, ${ }^{7}$ in which he analyses the plurality of cultures in urban milieus, foremost in Vienna. In his book reviewed here, Csáky develops further some of his ideas already presented in the operetta book, and sheds more light on the background of the phenomena introduced in his book on urban milieus. At first glance, the structure of Das Gedächtnis Zentraleuropas falls short in elegance compared to the operetta book. The brief preface is followed by a 120-page "Introduction", where a series of concepts are presented from the field of cultural studies, which the historian considers useful in dealing with Central Europe. These theoretical and methodological considerations are demonstrated in the following four chapters on four authors: Fanz Kafka, Hermann Bahr, Joseph Roth, and Miroslav Krleža. The next two chapters are organized around two specific subjects: the sixth deals with multilingualism, whereas the seventh analyses the creation of the "other". The final chapter highlights the relevance of the findings for contemporary Europe.

Nevertheless, the banality of the structure is illusory, because there is a constant dialogue between theoretical considerations and their demonstrations, and the chapters dealing with individual writers often change scale and address general problematics. Similarly, the isolation of the theoretical chapter also has a deeper significance than merely facilitating the reading process: by presenting the underlying ideas, Csáky also points to possible paths for future research. The historian probably agrees with François Furet's assumption that good historical research is above all a question well posed.

Although if approached in this way, the structure of the book may gain new meaning, in terms of representativity, the work still falls short compared to the undertaking on fin de siècle operetta, as it fails to recreate its brilliance. Surprisingly, Csáky does not use his impressive methodological tools at this point (probably the concept of "outillage mental" could have served him well) and short-circuits the question by affirming that literary works represent the current mentality of a society better than diplomatic files.

In the title, a conscious choice is made when the term Zentraleuropa (which is already familiar to us from his book on the cities) is used rather than Mitteleuropa. The reason is that the latter has severe ideological implications, as it refers to a German cultural imperialist idea. It is worth noting at this point that in the age of the Austro-Hungarian Empire, the region was already perceived in different ways, as Csáky informs us. In his synthesis of imperial history published as early as the 1870s, historian Franz Krones stated that studying the cultural history of the Empire's diverse peoples was necessary to understand the Austrian state, 
and sharply condemned the view of Austria as a German state, together with the Germanizing tendencies in the Empire's history. ${ }^{8}$ Richard von Kralik, on the other hand, who is primarily considered a literary man but also, in addition to many of his activities, a historian, thought that Germanizing endeavors were not to be condemned, as they were not ordered by the coercive power of the Austrian state but were dictated by a natural cultural process: he saw them as resulting from the superiority of the "unparalleled" German culture. ${ }^{9}$ In my view, we witness the rivalry between the concepts of Zentraleuropa and Mitteleuropa here, which only reinforces the relevance of Csáky's choice of his concept.

When defining Zentraleuropa, Csáky agrees with those writers who emphasize the undefinable nature of the region; however, he is not content with merely affirming this fact. He describes Central Europe as a relational space (relationer Raum), and proclaims a break with traditional mapping, as this visualizes political power relations and demands. The depiction of Central Europe as an enclosed space, the way essentialist conceptions suggest, is not relevant to social and cultural studies. Contrary to these representations, Csáky turns to those thinkers, above all Georg Simmel, Michel De Certeau, Henri Lefebvre, and Yuri M. Lotman, who captured space not as a clearly demarcated unit, but as a performatively created, dynamic process: for them, space is a set of social actions and symbolic codes constructed by social-psychological interactions. Perceived as a space of contact, this region also took on a real territorial form in the image of the multi-ethnic Habsburg Empire, which can consequently be seen as a historical-political concretization of Central Europe as a close coexistence of different peoples, cultures, languages, religions, and social groups.

Turning to the rest of the work, I find it more expedient to break with the linear presentation; instead, I will proceed along the main concepts introduced in the theoretical introduction, and in reference to them, include the findings in the subsequent demonstrative chapters. Due to its rich implications, the sixth chapter on multilingualism, which I will discuss separately, will be an exception. As a person interested in the Habsburg Empire, I focus primarily on Csáky's contribution to research in this field; nevertheless, this touches on many factors, given the fact that Csáky sees the Empire as a historical-political concretization of Zentraleuropa. I also consider it beneficial to present the author's findings and theoretical-methodological considerations by comparing them with the most exciting historical trend in recent research on the Habsburg Empire, usually associated with the name of the American historian, Pieter M. Judson. This has been especially justified since 2016 when Judson presented the most important results of the trend in a grandiose synthesis. ${ }^{10}$ This comparison

\footnotetext{
8 Krones, Handbuch der Geschichte Oesterreichs.

9 Kralik, Österreichische Geschichte.

10 Judson, The Habsburg Empire.
} 
will show that the difference between these two important personalities' research into the Empire is mostly imaginary, but in some cases it is real.

Let us start this presentation by examining the concept of identity. Although it undoubtedly occupies a central place in Csáky's monograph, he does not pay as much attention to it as to the concepts of culture, frontier, or space. Yet, the term would be worthy of the attention of a researcher with such outstanding theoretical training, both because of its central significance and the recent debates surrounding it. Furthermore, it is also widely used in public life, and Csáky obviously considers it important to distinguish the historian's definitions and findings from ordinary perceptions and from the political use of the concepts. It was precisely the overuse of "identity" that led prominent researchers like Rogers Brubaker to announcing a break with it. In a joint study with Frederick Cooper, Brubaker pointed out, among other things, that the concept of identity is, on the one hand, too static and, on the other, involves too many internal contradictions to be a truly useful analytical tool. ${ }^{11}$ Judson, who does not usually provide his readers with explicit theoretical considerations, seems to be of the same opinion as Brubaker. Most often, he points out the fact that identity cannot be considered solid but is situation-bound, and is in constant motion, consequently it is more appropriate to speak of identification processes rather than identities. Thus, on several occasions, Judson speaks of self-identification rather than identity. ${ }^{12}$ Although Csáky refers to Brubaker, he does not cite his famous study which declares war on the concept of identity. Csáky frequently uses the term, arguing most of the time that one should speak of hybrid identities in relation to Central Europe, which he demonstrates through such cultural icons as Gustav Mahler, who was in a permanent crisis in his quest to reconcile his many-layered identities (Bohemian German, Austrian, and Jewish). In a keynote speech held in Ljubljana, Judson evaluates the term hybrid identity as a barren attempt to transcend the fundamental limitations of the concept of identity that prevent us from being able to describe a wide range of identification processes. Csáky himself considers that identity is a multipolar phenomenon, which is constantly evolving, and changing depending on the experiences and the internalization of these experiences. In the meantime, the historian refuses to replace the concept with a term that would express more adequately this aspect of constant movement and change. Obviously a serious feat for them, Csáky strengthens the camp that does not identify with Brubaker's position and thinks the concept of identity is still useful, but draws attention to the importance of the reflected use of the concept. ${ }^{13}$

\footnotetext{
11 Brubaker and Cooper, "Beyond Identity."

12 Judson, "Introduction," 1-18.

13 For example: Abdelal et al., "Identity as a Variable."
} 
Culture is a central notion for Csáky, and Judson's Chapter 6 (Culture Wars and Wars for Culture) in the above-cited synthesis, The Habsburg Empire, is also organized around this notion. In this chapter, Judson presents how different activists of all stripes of the Austro-Hungarian society referred to the authority of what they called "culture" in order to formulate their vision of the Empire, and sharpened differences with their opponents. In the activists' vision, these "cultures" (of which national culture is crucial, but far from being the only one) were separated by insurmountable contradictions; however, everyday life constantly refuted this assumption. ${ }^{14}$ As a result, culture is a notion which historians need to use with extreme caution so that they do not simply reproduce the visions of contemporary activists, which is an error that, according to Judson, many historians have committed in the past. Csáky avoids this trap by defining culture as a dynamic, hybrid and complex space of communication. For him, culture is a set of signs that enables people to make themselves understood; language is only one of many elements. To conceptualize this, Csáky draws on Lotman's theory of the semiosphere, which refers to an abstract yet real space whose essence is heterogeneity. Different signs compete within this space and interact dynamically with each other, their relationship ranging from complete translatability to untranslatability. A flagrant example of the hybrid cultural configurations of Central Europe is the musical world of Vienna. This practice-oriented approach, which sees culture as a set of signs, refutes the concept of national culture that implies a closed, homogenizing, essentialist notion of culture, which is what Judson's activists referred to.

Frontier is central to Lotman's theory of the semiosphere, and consequently also to Csáky's concept of culture. Once again, we have a notion that is of great importance for Judson. In one of his most exciting books, the American historian deconstructed the notion of language frontier. He points out that the view of mixed-language areas as "language frontiers" provided an opportunity for national activists to simplify the complex reality of these regions through the political interpretation of the frontier, which implies a conflicting relationship. It is not so much a real space, but rather the result of activists' efforts to place mixed-language regions in their thinking, which could only make sense to them in the form of nations striving for hegemony at each other's frontiers. ${ }^{15}$ Once again, we are faced with a notion the use of which can lead to the adoption of the national activists' worldview. However, this is still not the case with Csáky. He thinks of the frontier in the spirit of Lotman's semiosphere-theory, accordingly, as a zone where the signs cluster. On the one hand, frontiers divide, because different signs, symbols, codes or even people and social groups meet, confront each other, and define themselves

14 Judson, The Habsburg Empire, 269-75.

15 Judson, Guardians of the Nation. 
in their opposition to the other. For nationalist ideologies, frontiers existed only in this sense: they were a zone of forceful conflict, where translation is neither possible nor desirable. Nevertheless, frontiers also unite, as they make communication and interaction possible between the sides. In this way, they can function as a zone of contact, where crossings and translations can be realized. This perception of culture and frontier does not lead Csáky to draw an idealized picture of the Empire. The concurring, contradictory and overlapping communicational spaces (cultures) do not only inspire creativity but also lead to uncertainty, crises, and conflicts as well, which are important characteristics of the Central European region. In his analysis in Chapter Two, Csáky shows how this situation is depicted in Kafka's 1917 novel, where China serves as the metaphor of the empire, where people's inner uncertainty is a greater threat than the invading enemy.

As an editor, organizer, and author, Csáky had been at the forefront of applying current theoretical and methodological trends in research into the region. Thanks to these efforts, important volumes have been published on how such concepts as lieux de mémoire, ${ }^{16}$ spatial turn, ${ }^{17}$ or postcolonialism ${ }^{18}$ can be applied to the history of the region. Postcolonialism stands out as important in the present book as well, foremost in the analysis of Joseph Roth's Das Falsche Gewicht. However, several researchers, including Pieter M. Judson, have expressed concerns about the applicability of the postcolonial discourse. In their view, this would confirm the narrative of the nationalist activists. The researcher would thereby introduce concepts into the legitimate scientific language that activists of the era used to manipulatively describe the relationship between their nations and the Empire. ${ }^{19}$ Perhaps it is sufficient to cite the example of the Hungarian independents of the Austro-Hungarian Empire who complained about the colonization of Hungary. The past "colonial" status of Poland and Ukraine is also an integral part of the myths of national victimhood critically examined by Csáky in other contexts. In fact, we face the problem that Reinhart Koselleck pointed out in his excellent study of asymmetric counter-concepts: there is a serious danger in learning about historical processes based on the same counter-concepts as those that contemporaries experienced and used for interpreting the world, as these strict dualities are created for their political effectiveness. Historical research should not base its interpretation on the same dualities in which contemporaries interpreted their world. ${ }^{20}$

\footnotetext{
16 Le Rider, Csáky, and Sommer, Transnationale Gedächtnisorte in Zentraleuropa.

17 Csáky and Leitgeb, Kommunikation - Gedächtnis - Raum.

18 Feichtinger, Prutsch, and Csáky, Habsburg postcolonial.

19 Cp. Surman, "Postkolonialismus," 181-87.

20 Koselleck, “Zur historisch-politischen Semantik," 211-59.
} 
Thanks to his theoretical reflections, Csáky evades this trap. From postcolonial studies, he primarily adopts the theory of Homi K. Bhabha about the "third space" in order to more fully grasp the processes taking place at the frontier. By third space, Bhabha means a frontier zone, in which migration and mobility take place, and which is in constant movement. It is in this space that cultural codes and traditions meet and mutually influence each other. This third space is not only an abstract notion of cultural history but can actually be identified in the age of Austro-Hungary. These spaces create hybrid identities, which the author demonstrates by evoking the personalities of the writer Scipio Slataper and the composer Gustav Mahler. The notion of third spaces questions the validity of the vision of a homogenous, authentic national culture and thus evades the dangers Judson points out. In fact, it paints a picture of the processes that take place at the frontiers that are similar to what Judson shows in his empirical research.

Nevertheless, it seems that the application of the terminology of postcolonialism has its downsides. Several scholars have drawn attention to the fact that the application of metaphors and notions of the colonial rule to European phenomena leads to a simplifying interpretation, as it divides the world into wrongdoers and victims, and leads to significant nuances being glossed over. To give an example from my field of research: the problem of interpreting the past, which is also an important area in Csáky's work. Krijn Thijs warns his readers by analyzing the metaphor of the master narrative, that its "master-slave" interpretation according to which master narratives suppress slave stories, while legitimately emerging in a certain colonial context, is inadequate for the analysis of European processes. Instead of a "master-slave" interpretation, he suggests a master-copy interpretation of the master narrative that implies a model-value master narrative that provides a dominant version of the past in terms of its structuring and the meaning attributed to the past. ${ }^{21}$ In this spirit, in connection with the interpretations of history from the imperial center, it is more advisable to think of applying the concepts of adaptation and resilience. Incidentally, these current concepts of social sciences seem to be applicable in various areas of the Empire's history, therefore they could have been addressed in Csáky's long methodological introduction.

In the field of historiography, the case of Václáv Vladivoj Tomek is a telling example of adaptation. The work of Tomek, historian at the Charles University in the 1850s, was influenced by the ideas of Leo Thun's secretary of state for education, Joseph Alexander Helfert. Helfert expected historians to create an identity-creating narrative to project the idea of Great Austria back into history. At first glance, Tomek realized Helfert's idea, but at the same time reshaped it slightly but noticeably in line with his own Czech-Slavic national sympathies. In his work, Rudolf of 
Habsburg's victory over the Bohemian King Ottokar was not presented as one of the great moments of the founding of Austria, but a deviation from the road leading to it. The Bohemian king was seen as the first to create an empire comparable to Austria, that, due to his defeat, would come into being only in $1526 .{ }^{22}$ Clearly, we are not faced with the interpretation of the past forced on the colonized by the colonizer, but with a creative adaptation of the guidelines from the center, which takes local peculiarities into account.

As indicated above, the sixth chapter on the language issue is reviewed separately because of its significant implications. In one of his long studies, Gerald Stourzh, an outstanding researcher of the Habsburg Empire, thoroughly criticizes the concept of national indifference used by Pieter M. Judson (and researchers with similar historical views, such as Tara Zahra and Jeremy King). He acknowledges that certain forms of national indifference could indeed be clearly identified but considers it more important to analyze the Empire's complex linguistic conditions. While national indifference may surely exist, Stourzh argues, linguistic indifference is impossible. ${ }^{23}$ The basis of Csáky's analysis is the theory of Robert W. Evans, who considers that the language issue was the most important problem of the Habsburg Empire, and that it was essentially more responsible for its fall than political differences. This is the reason why it is not the political aspects of national conflicts that need to be addressed, but the social history of language. In connection with the use of language, Csáky points to a threefold process that proved to be fatal for the Empire. Multilingualism in the region is a rule rather than an exception (as illustrated by the example of Arthur Koestler), which means not only the knowledge of several languages, but also identification with the social groups and cultures represented by the languages. However, censuses from 1880 onwards required everyone to specify a single language as their language of use (Umgangsschprache), which was very far from the actual social practice. This played into the hands of national ideologists, who identified language as a criterion of national belonging. Thus, in the depths of nationalist political battles, the issue of language can be detected. For explaining why national ideologues found language as a criterion of national affiliation, Csáky turns again to the concept of the semiosphere. In the Central European semiosphere, it is a mere illusion that there are homogeneous communication spaces hermeneutically isolated from each other-in fact, there are plenty of contact zones between them. The contact of cultural spaces leads to mixes and similarities that are most evident in everyday life. In essence, only the specific, spoken language has the characteristics that allow for clear differentiation, thus understandably gaining symbolic power in the context of nation-building. This sheds light on why practical

22 Tomek, Handbuch der österreichischen Geschichte.

23 Stourzh, "The Ethnicizing of Politics," 283-323. 
measures concerning language use could swell into political chaos, as has been the case with the Badeni regulations of $1897 .{ }^{24}$

Finally, let us go back to the opening idea of this review: Moritz Csáky's research is guided by the contemplation of the present, and high sensitivity to contemporary problems. This does not mean instrumentalizing history, but rather analyzing past phenomena that show structural similarities with today's dilemmas, thus teaching us to conceptualize them. In the last chapter, Csáky gives an explicit overview of the main European dilemmas of our days. Of these, I will only touch briefly on the issue of a common interpretation of the European past. Csáky rejects the ambition to create a common European memory in which the French, Poles and Germans, for example, have a unified image of each historical event. Instead, Europeans should recognize that the memory of their neighbors is as legitimate as their own. Translated into the vocabulary of the pact mémoriel, a concept developed by André Burguière ${ }^{25}$ this could be formulated in the following way: the European pact mémoriel should not be imagined as a forced agreement on a common interpretation of certain historical events, in which the parties end up making compromises far beyond their tolerance leading to a pact that no one really feels their own. Instead, this pact must touch the deeper layers of our thinking and replace the reflex of striving for homogenization and unification at all costs with the intention of accepting diverse experiences.

\section{Bibliography}

Abdelal, Rawi, Yoshiko M. Herrera, Alastair Iain Johnston, and Rose McDermott. "Identity as a Variable." In Measuring Identity: A Guide for Social Scientists, edited by Rawi Abdelal, Yoshiko M. Herrera, Alastair Iain Johnston, and Rose McDermott, 17-32. Cambridge: Cambridge University, 2009. https://doi. org/10.1017/CBO9780511810909.002.

Bloch, Marc. The Historian's Craft. Manchester: Mancherster University Press, 2004.

Brubaker, Rogers and Frederick Cooper. "Beyond Identity." Theory and Society 29, no. 1 (2000): 1-47. https://doi.org/10.1023/A:1007068714468.

Burguière, André. "Nemzeti örökség, emlékezet és történelem" [National Heritage, Memory and History]. In Vis-á-vis: Tanulmányok az Atelier fennállásának 25. évfordulójára [Vis-à-vis: Studies in Honor of the $25^{\text {th }}$ Anniversary of the Atelier's Creation], edited by Péter Erdősi and Judit Klement, 145-66. Budapest: Atelier Európai Társadalomtudományok és Historiográfia Tanszék, 2015.

24 The regulation of 1897 declared that both Czech and German should be the language of administration in Bohemia, implying that civil servants in the region must know both languages, which outraged German nationalists. 
Csáky, Moritz. Das Gedächtnis der Städte: Kulturelle Verflechtungen; Wien und die urbanen Milieus in Zentraleuropa. Vienna-Cologne-Weimar: Böhlau, 2010. https://doi.org/10.7767/boehlau.9783205790716.

Csáky, Moritz. Ideologie der Operette und Wiener Moderne: Ein kulturhistorischer Essay zur österreichischen Identität. Vienna-Weimar-Cologne: Böhlau, 1996.

Csáky, Moritz and Christoph Leitgeb, eds. Kommunikation - Gedächtnis - Raum: Kulturwissenschaften nach dem "Spatial Turn" (Kultur- und Medientheorie). Bielefeld: Transcript Verlag, 2009. https://doi.org/10.14361/9783839411209.

Deák, Ágnes. “Európa kicsiben: Beszélgetés Csáky Móriccal” [Europe in Miniature: A Conversation with Moritz Csáky]. Aetas 13, no. 2-3 (1998): 238-49.

Feichtinger, Johannes, Ursula Prutsch, and Moritz Csáky, eds. Habsburg postcolonial: Machtstrukturen und kollektives Gedächtnis. Innsbruck-Vienna-MunichBozen: Studien Verlag, 2003.

Hebbel, Friedrich. "Prolog zum 26. Februar 1862 (Zu Wien im Operntheater gesprochen)." Die Deutsche Gedichte-Bibliothek. Accessed March, 18 2021. https:// gedichte.xbib.de/Hebbel_gedicht_Prolog+Zum+26.+Februar+1862.htm.

Judson, Pieter M. Guardians of the Nation: Activists on the Language Frontiers of Imperial Austria. Cambridge-London: Harvard University, 2006.

Judson, Pieter M. The Habsburg Empire: A New History. Cambridge-London: Harvard University Press, 2016. https://doi.org/10.4159/9780674969346.

Judson, Pieter M. "Introduction." In Constructing Nationalities in East-Central Europe $=$ Constructing Nationalities in East-Central Europe, edited by Pieter M. Judson and Marsha L. Rozenblit, 1-18. New York-Oxford: Berghahn Books, 2005. https://doi.org/10.2307/j.ctt1x76fbj.8.

Koselleck, Reinhart. "Zur historisch-politischen Semantik asymmetrischer Gegenbegriffe." In Vergangene Zukunft: Zur Semantik geschichtlicher Zeiten, 211-59. Frankfurt am Main: Suhrkamp Verlag, 1992.

Kralik, Richard von. Österreichische Geschichte. Vienna: Adolf Holzhausen, 1913.

Krones, Franz. Handbuch der Geschichte Oesterreichs von der ältesten bis zur neuesten Zeit: Mit besonderer Rücksicht auf Länder-, Völkerkunde und Culturgeschichte, I-IV. Berlin: Grieben, 1879.

Le Rider, Jacques, Moritz Csáky, and Monika Sommer, eds. Transnationale Gedächtnisorte in Zentraleuropa. Innsbruck: Studienverlag, 2002.

Schorske, Carl E. Fin de siècle Vienna: Politics and Culture. New York: Alfred A. Knopf, 1980.

Surman, Jan. "Postkolonialismus." In Habsburg neu denken: Vielfalt und Ambivalenz in Zentraleuropa; 30 kulturwissenschaftliche Stichworte, edited by Johannes Feichtinger and Heidemarie Uhl, 181-87. Vienna-Cologne-Wiemar: Böhlau, 2016. https://doi.org/10.7767/9783205204398-023. 
Stourzh, Gerald. "The Ethnicizing of Politics and 'National Indifference' in Late Imperial Austria." In Der Umfang der österreichischen Geschichte: Ausgewählte Studien 1900-2010, 283-323. Vienna-Weimar-Cologne: Böhlau, 2011. https:// doi.org/10.7767/boehlau.9783205791461.283.

Szívós, Erika. "A másik Bécs" [The Other Vienna]. In Az öröklött város: Városi tér, kultúra és emlékezet a 19-21. században; Történeti tanulmányok [The Inherited City: Urban Space, Culture and Memory from the $19^{\text {th }}$ to the $21^{\text {st }}$ Century; Historical Studies]. Budapest: Budapest Főváros Levéltára, 2014.

Thijs, Krijn. "The Metaphor of the Master: 'Narrative Hierarchy' in National Historical Cultures of Europe." In The Contested Nation: Ethnicity, Class, Religion and Gender in National Histories, edited by Stefan Berger and Chris Lorenz, 60-74. New York: Palgrave Macmillan, 2008.

Tomek, Václáv Vládivoj. Handbuch der österreichischen Geschichte. Prague: Tempsky, 1858. 